\title{
Middle-Income Trap - Threat or Reality
}

\author{
Bozena Leven
}

\begin{abstract}
The middle-income trap (MIT) describes obstacles to sustainable growth experienced by some middle-income countries. The initial growth of emerging economies is often characterized by reliance on labor intense, import driven factors, facilitated by foreign direct investment (FDI). As it matures, that initial growth becomes more dependent on foreign technology imports to produce exports, which can impede sustained growth. Poland is representative of several middle-income East European countries; after the 1990 transition, Poland had inadequate infrastructure and obsolescent industries, but a work force that was highly educated. Since 1990, relatively low labor costs, technology imports, European Union (EU) funding, and FDI have propelled Poland to middleincome status. However, Poland's comparative labor advantages have recently diminished, while both the quantity and composition of FDI inflows are changing. In this paper, we examine whether some growth factors have been exhausted, leaving Poland subject to MIT. To answer this question, we assess changes in investment and factor productivity, labor force educational attainments, FDI, new product/technology development, imports, export diversification, product complexity, and other factors. We conclude that in Poland several conditions consistent with MIT are gaining importance and may be an early warning sign of challenges to its future growth.
\end{abstract}

KEY WORDS: $\quad$ Economic growth and aggregate productivity, international factor movements, middle income trap.

JEL Classification: F2, F20, 04.

School of Business The College of New Jersey, Ewing, NJ 08628 SGH/KGS

\section{Introduction}

Most countries that have reached middle level of development (as measured by per capita GDP) rely on high value-added production, as growth engines to produce relatively low costs exports that embed domestic labor, foreign technology, and/or capital. For most of these countries, this development model is not sustainable in the long-term.

Several factors described by the middle-income trap (MIT) are more than a measure of GNP or per capita income. The MIT also speaks to, and provides a way to understand, the phases of an economy's development. The characteristics that suggest a MIT phase are diminishing factor productivity due to the exhaustion of labor-intensive factors, as well as shifting import and foreign di-

Correspondence concerning this article should be addressed to: Bozena Leven, School of Business The College of New Jersey, Ewing, NJ 08628.

E-mail: bleven@tcnj.edu rect investment (FDI) based strategies. Our focus in this paper is on whether Poland is subject to the MIT. Over the last twenty years, Poland has enjoyed steady economic growth resulting largely from technology imports, relatively low labor costs, and generous EU structural subsidies and funds. While economic growth is only one aspect indicating a threat of MIT, it is worth noting that it has recently slowed, raising the possibility that Poland is experiencing an MIT. To explore that possibility, we analyze changes in factor productivity, investment (i.e., its growth and composition), labor force educational attainments, FDI, new technology and product development, imports, export diversification, and product complexity. The development of Poland's institutions and infrastructure are also assessed, along with demographic changes conducive to growth. We find that several factors consistent with the MIT are gaining importance in Poland and may inhibit its growth rate in the future. 


\section{The Controversy over the MIT in the Literature}

The concept of a middle-income trap is relatively recent, having first been analyzed in detail by the World Bank when examining certain economic slowdowns in Asia, and their macroeconomic conversion problems (Gill \& Kharas, 2007). Following that initial work, a substantial body of literature has emerged about the causes and parameters of the MIT, along with policies to mitigate or prevent it from occurring. The literature describing the MIT can generally be divided into two somewhat overlapping groups: the first being definitional, which seeks to identify statistical evidence of a slowdown in macroeconomic measures of growth and development; the other seeks to describe a pathway to alleviate such slowdowns by linking them to insufficient institutional and structural reforms needed to propel a country's economic development past the middle-income stage. More generally, the MIT can be understood as describing discernible, multi-year economic slowdown facilitated by systemic reasons that hinder income growth and may prevent an economy from becoming fully developed.

The notion of a "trap" is derived from Nelson's "lowlevel equilibrium trap", which he used to describe diverse low-income countries unable accelerate their growth (1956). Although precise income levels, specific growth rate declines, and timeframes involved in the MIT are not well-defined in the literature (Griffith, 2011), there is a general consensus that the MIT presupposes that the subject country has capita income in the "teens" of thousands of dollars (Eichengreen, 2011).

A lack of uniform definitions and precise numerical measures that characterize the MIT are made more problematic by the multitude of changes and structural characteristics that economies threatened by the MIT may exhibit (Radwan, 2014). Arguably, countries that do not face an MIT threat (e.g., countries that either insufficiently developed, or too developed for an MIT to exist) are easier to identify than those at risk of the MIT. The former includes economies characterized by slowgrowth, and rely on labor intensive low-skill production, foreign capital supplementing low domestic savings and low diversification of exports, and natural resources (Baumol, 1967). By contrast, countries with a per capita income exceeding $\$ 20,000$, with an accumulated stock of physical and human capital, high-skill labor, and capital-intensive production that originate from domestic innovation and technologies, and high and rising total factor productivity are not at MIT risk (Gill \& Kharas, 2007; Yusuf \& Nabeshima, 2009; Woo \& Heo, 2009; Jankowska et al., 2012). In the space between developing and mature economies we find countries at MIT risk (Rostow, 1990).

For example, Brazil, after strong growth in the 1950s through the 1970s, is currently mired at 1980 income levels, limited export diversification, slow productivity growth, and weak or declining institutional progress, as indicated by its Gini coefficient, governance, and corruption indices (World Bank Annual Report, 2015). China's post-2009 slowdown in growth has also caused researchers to examine whether China will likely experience an MIT, and various factors that might contribute to it (Zhan, 2013).

The benchmarks, circumstances, and growth metrics these two countries face are quite different. The utility of the MIT is that it provides an analytical overlay to assess widely differing countries that seek to move to the third stage of their development. That overlay does not depend on country-specific (and therefore non-transferable) empirical evidence, but instead pulls together characteristics broadly understood as posing challenges to countries previously propelled by economic growth, which can no longer do so.

Table 1 summarizes a number of general features that characterize a country's expected growth progression from low income (shown at the left) to the most advanced level of development (shown at the right), which is divided into five stages. The literature suggests that MIT is most likely to occur between stages III and IV (Rostow, 1990).

In stage I of development natural resource or agricultural specialization occurs, leading to production of labor intensive/low wage goods and use of imported (or imitating) capital and technologies from more advanced countries that foster economic growth. Typically, the shift to stage II is characterized by a reallocation of capital and the workforce from the natural resource/agricultural sectors to more productive service and/or industrial sectors. This shift is often supported by both active government support and capital inflows. Appropriate institutional adjustments and policies, capital inflows, increased savings and productivity, can expedite a country's ability to move to 
Table 1

Major Stages of Economic Growth and Development

\begin{tabular}{|c|c|c|c|c|}
\hline I. & II. & III. & IV. & V. \\
\hline $\begin{array}{l}\text { Reliance on subsis- } \\
\text { tence agriculture, aid } \\
\text { dependency }\end{array}$ & $\begin{array}{l}\text { Introduction of sim- } \\
\text { ple manufacturing } \\
\text { involving foreign } \\
\text { capital }\end{array}$ & $\begin{array}{l}\text { Complex manufac- } \\
\text { turing/continued } \\
\text { reliance of foreign } \\
\text { capital }\end{array}$ & $\begin{array}{l}\text { Quick absorption of } \\
\text { foreign management } \\
\text { and technology; start- } \\
\text { ing to produce and } \\
\text { develop own goods }\end{array}$ & $\begin{array}{l}\text { Reliance on own in- } \\
\text { novation, product } \\
\text { design; global lead in } \\
\text { many products }\end{array}$ \\
\hline $\begin{array}{l}\text { 1. low growth in per } \\
\text { capita income }\end{array}$ & $\begin{array}{l}\text { 1. moderate growth } \\
\text { of per capite income }\end{array}$ & $\begin{array}{l}\text { 1. rising per capita } \\
\text { income growth }\end{array}$ & $\begin{array}{l}\text { 1. rapid structural } \\
\text { change }\end{array}$ & $\begin{array}{l}\text { 1. steadily increased } \\
\text { TFP growth }\end{array}$ \\
\hline $\begin{array}{l}\text { 2. agricultural em- } \\
\text { ployment exceeding } \\
80 \text { percent }\end{array}$ & $\begin{array}{l}\text { 2. moderate struc- } \\
\text { tural change }\end{array}$ & $\begin{array}{l}\text { 2. moderate struc- } \\
\text { tural change }\end{array}$ & $\begin{array}{l}\text { 2. shift of the employ- } \\
\text { ment share from ag- } \\
\text { riculture to industry } \\
\text { and services }\end{array}$ & $\begin{array}{l}\text { 2. high capital and } \\
\text { technology content } \\
\text { of production and ex- } \\
\text { ports }\end{array}$ \\
\hline $\begin{array}{l}\text { 3. government driven } \\
\text { industrialization, wide } \\
\text { use of subsidies }\end{array}$ & $\begin{array}{l}\text { 3. increase of non- } \\
\text { agricultural labor }\end{array}$ & $\begin{array}{l}\text { 3. increased non-ag- } \\
\text { ricultural labor }\end{array}$ & $\begin{array}{l}\text { 3. increased labor } \\
\text { productivity and par- } \\
\text { ticipation }\end{array}$ & \\
\hline $\begin{array}{l}\text { 4. limited structural } \\
\text { change }\end{array}$ & $\begin{array}{l}\text { 4. infrastructure } \\
\text { build up }\end{array}$ & $\begin{array}{l}\text { 4. formation of a do- } \\
\text { mestic service indus- } \\
\text { try (outside of tradi- } \\
\text { tional services) }\end{array}$ & & \\
\hline Rwanda, Ghana & Vietnam & Thailand, Malaysia & South Korea, Taiwan & $\begin{array}{l}\text { Us, Japan, most of the } \\
\text { EU }\end{array}$ \\
\hline
\end{tabular}

Source: based on Rostow's Stages of Economic Growth (1959)

stage III. And to evade the MIT it is there - at stage III where growth has to shift from (i) existing comparative advantages concentrated primarily in exploiting natural resources and/or low labor costs to (ii) increasing total factor productivity and developing new technology and innovation-based engines of growth (Porter, 2002), the latter resulting from investment in human capital.

\section{Factors Posing an MIT Risk - the case of Poland}

As previously noted, what underlies the MIT is the changing role of factors that previously supported growth in low-income countries before they reached middle-income status. That is, reliance on labor intensive production processes, the widespread use of imported technologies, and direct foreign investment become less viable growth engines as economic development pushes a country's domestic prices and wages higher. That spiral then requires increased productivity of labor and capital, facilitating rising total factor productivity, developing new technologies and innovation. In this section we explore challenges associated with sustainable economic growth and a progression to higher stages of development (in Table 1, from stage III to stages IV and V).

In addition to declining total factor productivity, there are several other factors that may contribute to MIT (Martin, 2017). Among these factors are: slow growth and the composition of investment (potentially exacerbated by prior high government investment rates that were unsustainable due to insufficient support by domestic savings) (Hayat 2014); a heavy reliance on FDI as a funding mechanism for domestic investment; lagging labor force educational attainments (Leibfritz \& Roeger, 2008); the absence of new technologies and products; an overreliance on capital and technology intensive goods imports (Mishal \& Abulaila, 2007); insufficient R\&D; a lack of export diversification; and 
limited product complexity. In addition, the slow development of modern infrastructure, unstable institutions (particularly those relating to the legal environment), and unfavorable demographics (North, 1989) further the possibility of an MIT.

The test for an MIT threat can be also signaled by a country's changing economic complexity, (Pietronero 2013), which can be used to measure a country's sustainable growth potential. Economic complexity generally refers to interactions among a country's intangible, non-monetary and non-tradable assets that facilitate production. It has been argued that a country's competitiveness and growth potentials are based on the complexity of its production and non-cost competitiveness.

When considering all these factors in the context of Poland's economy, which is at development stage III, mixed results emerge. The sustainability of Poland's growth has recently received attention in the academic literature (Radwan, 2014; Pruchnik \& Toborowicz, 2014), in part, due to several arguably unique characteristics of its economy. In particular, Poland was the only country to transition from a market economy in the 1990s that maintained positive growth rates during the great recession and financial crisis. Table II illustrates several attributes of that growth which, after the great recession ended, has fluctuated. In it, we see that Poland's 4.1 percent average growth rate from 2001 to 2008 declined to 2.9 percent during the 2009 to 2016 period. As a country's economy expands it is unrealistic to expect its growth rates to continuously rise. A flattening of the growth rate is, however, open to interpretation; it can be a part of the expansion of a mature economy involving structural changes or indicate an economic slowdown caused by imbedded systemic factors. The eight-year period (2009 to 2016) examined is too short to reveal definite trends, and Poland's economic slowdown (particularly in light of the global recession) does not necessarily imply systemic threats. Nevertheless, the slowdown does coincide with the emergence of several systemic factors that may contribute to, and are consistent with, an MIT. We turn now to those factors.

In doing so, it is worth noting that Poland's growth is measured using GDP/capita. Arguably, given the size of repatriated profits from Poland, GNI/capita might be a more suitable growth indicator. However, insofar as other growth measures we use are calculated in relation to GDP (and not GNI), such as the share of investment or research and development, our use of GDP is used to facilitate consistency among growth measures

Factor productivity slowdowns or declines are a key factor that may prompt an MIT. Although total factor productivity estimates routinely rely on multiple (and possibly problematic) assumptions, productivity trends are frequently used to assess an economy's strength (Van Biesebroeck, 2007; Felipe, 1999). In the literature, differences in the results obtained when measuring productivity are often attributed to differences in the methodologies used (Syverson, 2011). In this study total factor productivity refers to the traditional productivity measure as opposed to endogen factors of productivity (knowledge, innovation, etc.). Even so, it is generally accepted that measuring factor productivity as aggregate numbers can, and often does, hide subtle labor and capital market changes. Reliance on productivity cross-sectional data for different economies therefore tends to provide a less accurate picture of the actual situation being experienced on the ground. By contrast, single country series time series data using a consistent methodology may more accurately reveal the economic progress of a specific economy.

Typically, factor production prices rise as growth continues, often depressing productivity. In this study we measure total factor productivity (TFP) per hour, in dollars of output per hour. This number has been rising steadily (excepting 2010), albeit at an uneven rate. A similar pattern can be discerned in the growth of GDP values in dollars per hour worked, which is may be considered a labor productivity proxy. This productivity growth reinforces the notion that Poland's comparative advantage still stems from its relatively low labor costs. In fact, the Eurostat (2019), ranked Poland 21 (next to Latvia, Brazil Turkey and Argentina) in average labor costs, indicating that Poland still relies on cheap labor to compete and earn its export position and has not moved to a more capital/technology-based growth stage.

In addition to TFP, another way of assessing changing productivity trends is by tracking Poland's competitiveness. The IMD World Competitiveness Ranking based on 235 indicators calculated using surveys and various statistical sources from 63 
Table 1

Major Stages of Economic Growth and Development

\begin{tabular}{lllllllllllllllll}
\hline Year & $\mathbf{2 0 0 1}$ & $\mathbf{2 0 0 2}$ & $\mathbf{2 0 0 3}$ & $\mathbf{2 0 0 4}$ & $\mathbf{2 0 0 5}$ & $\mathbf{2 0 0 6}$ & $\mathbf{2 0 0 7}$ & $\mathbf{2 0 0 8}$ & $\mathbf{2 0 0 9}$ & $\mathbf{2 0 1 0}$ & $\mathbf{2 0 1 1}$ & $\mathbf{2 0 1 2}$ & $\mathbf{2 0 1 3}$ & $\mathbf{2 0 1 4}$ & $\mathbf{2 0 1 5}$ & $\mathbf{2 0 1 6}$ \\
\hline 1 & 1.2 & 1.3 & 3.7 & 5.6 & 3.4 & 5.8 & 6.6 & 4.8 & 1.7 & 3.8 & 4.4 & 2 & 1.3 & 3.3 & 3.7 & 3.1 \\
& & & & & & & & & & & & & & & & \\
2 & 14.4 & 15.7 & 16.5 & 17.8 & 18.1 & 19.1 & 20.3 & 21.4 & 22.7 & 22.5 & 27.5 & 28.8 & 29.9 & 30.4 & 31.2 & 32.0 \\
& & & & & & & & & & & & & & & & \\
3 & 90.5 & 82.1 & 83.5 & 87.5 & 94.2 & 108 & 126 & 138 & 149 & 154 & 168 & 164 & 156 & 166 & 173 & 175 \\
4 & 101 & 103 & 106 & 112 & 116 & 123 & 132 & 138 & 142 & 147 & 154 & 157 & 160 & 165 & 171 & 176 \\
5 & 103 & 108 & 123 & 129 & 142 & 164 & 181 & 193 & 182 & 206 & 222 & 232 & 246 & 263 & 283 & 308 \\
6 & 20.6 & 18.4 & 18.8 & 20.2 & 19.2 & 21.7 & 25.2 & 24.6 & 20.6 & 21.3 & 22.4 & 21.0 & 19.0 & 20.4 & 205 & 19.6 \\
7 & 1.1 & 1.3 & 1.4 & 1.5 & 1.6 & 1.9 & 2.0 & 2.0 & 2.0 & 2.2 & 2.5 & 2.5 & 2.5 & 2.5 & 2.7 & 2.6 \\
8 & 0.62 & 0.56 & 0.54 & 0.55 & 0.56 & 0.55 & 0.56 & 0.60 & 0.66 & 0.72 & 0.75 & 0.88 & 0.97 & 0.94 & 1.00 & \\
9 & 22.3 & 21.8 & 16.1 & 20.4 & 27.6 & 29.4 & 41.3 & 38.0 & 40.3 & 36.0 & 51.6 & 48.0 & 60.8 & 64.7 & 62.5 & 66.7 \\
10 & 61.5 & 62.2 & 62.9 & 63.4 & 64.0 & 64.2 & 64.4 & 64.5 & 64.5 & 64.4 & 64.2 & 63.9 & 63.4 & 63.0 & 62.4 & 61.9 \\
11 & 73.4 & 77.4 & 80.9 & 84.0 & 85.4 & 87.8 & 90.1 & 90.8 & 93.7 & 100 & 105 & 107 & 108 & 112 & 113 & \\
12 & 5283 & 3991 & 2897 & 2750 & 2223 & 4027 & 2689 & 6696 & 3799 & 3181 & 2424 & & & 9900 & \\
\hline
\end{tabular}

Sources: own calculations based on: CIA Country Factbook, OECD Statistics and Rocznik Statystyczny GUS Wskazniki Makroekonomiczne. Indicators are as follows: (1) growth: percentage growth rate of GDP (2) prod/hr, \$: total factor productivity per hour in dollars (3) I: investment index, year 2000=100 (4) VA: value added index, year $2000=100$ (5) X: exports index, year 2000=100 (6) I/GDP: share of investment in GDP (7) Ed: number of graduates with tertiary degrees outside of arts and sciences per 1000 (8) R\&D/GDP: share of Research \& Development in GDP (9) Pate: Number of patents/1000 (10) L: percent of population age 18-64 (11) Lprod: GDP per hour worked index, year 2000=100 (12) FDI: total FDI in million Euros

economies. The ranking relies on a wide range of data including unemployment, GDP and government spending on health and education, as well as data on innovation, corruption, IT skills and management sophistication. In 2018 Poland scored well regionally (Weresa 2017), but dropped from 34th to 38th in 2019, placing Poland behind such Southeast Asian countries as Malaysia, Indonesia, and Thailand (IMD, 2018; 2019 ).

A more mixed picture emerges from analyzing the composition, changes, and limited growth of investments in Poland. Private investment often has a tendency to be among the most volatile components of GDP because it is particularly responsive to cyclical fluctuations. Somewhat surprisingly, changes in the share of investment in Poland's GDP (I/GDP) reflect this sensitivity, even though public funds account for $75 \%$ of all investment (Fixed Assets in the National Economy in 2013). That predominance grew in importance during the 2008 to 2014 period, during which public investment rose (by share) 10 percentage points as private investment (by share) fell some 15 percentage points.

The explanation for this sensitivity is found in the sourcing of public investment, which reflects a reliance by Poland on EU funding of large capitalintensive projects; specifically, infrastructure (e.g., highways), broadband internet accessrelated initiatives, renewable energy sources, and environmentally friendly railways and public transportation. Internally, these funds, being expended through the Polish government, are booked as "public investment." Poland was among the top three largest recipients of EU funds from 2008 to 2015, and number one in 2013, when EU funding reached some $\$ 20$ billion. Indeed, this amount of EU funding has been difficult for Poland to absorb, which can threaten future inflows and has been cited by some as one reason for recent EU funding cuts (Szymański, 2017). 
Even though building infrastructure to facilitate modern growth often uses (and relies) on public funding, the high share and degree of EU funding may signal that the investment growth rates Poland previously enjoyed may not be sustainable over time. For example, the EU's investment in Poland is concentrated around "iron and concrete" (i.e., machines, roads, and buildings). Indeed, more than 75 percent of such funding during the 20142020 period was directed to Poland's infrastructure, transport, energy, and environment (Ortiz-Osipna, E., \& Beltekian, D. 2018). While "hard" investment in infrastructure is necessary to facilitate modern growth, it does not alone guarantee or even necessarily suggest that investment in knowledge and skills follow. Yet it is the latter form of investment that is the key to rising TFP and prevention of the MIT.

Data constraints (e.g., the relatively abbreviated time period analyzed, which coincides with a simultaneous global macroeconomic contraction), do not allow firm conclusions to be drawn about the likely direction of future investment growth rates. Nevertheless, Poland's investment composition is concerning. The relative lack of new private investment that competes with, and should eventually take the place of, the public investment of EU funded capital can impede growth sustainability. More analysis of factors and trends that impact the currently low, and declining, share of private investment in Poland over time will help solidify whether investment composition is or will, in fact, contribute to a systemic slowdown consistent with the MIT .

More generally, comparing Poland's investment growth with countries that avoided a MIT, as well as those still facing the MIT threat, presents a fluid and as yet undefined picture. According to the World Bank (2019) average annual gross capital formation in Poland was 7.87 percent in 2018, which is higher than that of Brazil (4.13 percent) and Malaysia (6.19 percent) in the same year. But Poland's capital formation growth lags behind, for example, Singapore (11.6 percent) or South Korea (10.11 percent), which are two countries that have successfully moved pass the MIT threat.

Another factor that can contribute to the MIT is educational attainments (Jimenez, 2012). In this area, Poland has made steady, sustained progress. Tertiary degree holders outside of arts and sciences have increased 2.6 times during the years examined, as the overall share of Poland's population with tertiary degrees - being 28 percent in 2015 - is on par with Germany's and higher than those of Portugal, Hungary, Italy, and the Czech Republic (Organisation for Economic Co-operation and Development [OECD], 2017a). At the same time, however, Poland's college graduates have persistently faced a shortage of attractive economic opportunities, as indicated by a large-scale emigration of skilled workers from Poland following the 2004 opening of the EU labor markets. Educational attainments without corresponding domestic job opportunities may not be a factor preventing the MIT.

Moreover, while Poland's educational attainments have many positive societal and cultural knock on effects, it apparently has not yet translated into product innovation. Measuring how innovation impacts, and increases, growth is difficult; though extensively (and effectively) measured for individual organizations, at the macroeconomic level attempts to quantify this feature typically use several proxies: the Research and Development (R\&D) share of GDP, the number of patents granted per 1,000 people (Sutz, 2012), the number of workers involved in R\&D per million people, and local innovation (European Commission, 2020).

The share of Poland's GDP expended on R\&D has increased in each examined year, though (at 1 percent of GDP), is the lowest among Europe's OECD countries. For example, the GDP shares for Germany, Hungary, Portugal, Italy, and Czech Republic are substantially higher - at 2.9, 1.4, 1.3, 1.3, and 2 percent of GDP, respectively.

Patents per 1,000 people increased from 22.5 to 66.7 in Poland during the 2000 to 2016 period. Poland nevertheless still ranks 20th in filings for intellectual property protection rights according to the World Intellectual Property Organization, Poland, placing it behind the majority of European countries at a similar level of development (Khan, 2016). The low rank in patent applications is also consistent with Poland's low R\&D spending, and could reflect, indirectly, limited support from the government for private innovation. 
The number of $\mathrm{R} \& \mathrm{D}$ researchers per million people in a country was developed by the World Bank. Under that measure, the average number of Polish researchers working on R\&D in 2017 was 2,543 per million; similar to Malaysia at 2,397 and Bulgaria at 2,125. In that same year, those numbers were 7,498 for South Korea and 5,026 for Hong Kong (World Bank 2018).

The Annual European Innovation Scoreboard 2020, which provides a comparative assessment of research and innovation performance of EU countries at the local level, ranks Poland in the third category of modern innovators. Using a multidimensional approach that, among other things, measures a country's cooperation with international partners and the share of innovation originating from small and medium size enterprises, Poland's progress between 2012 and 2019 has been quite modest; being slightly better than Hungary but behind Latvia and Lithuania (European Scoreboard 2020).

In summary, these limited data do not indicate that Poland is aggressively investing in or otherwise fostering home grown innovation. Instead, Poland's relatively low spending on $\mathrm{R} \& \mathrm{D}$, low ranking in patent applications and the relatively low number of R\&D workers per million people signal limited support for R\&D. This is likely leading to greater reliance on imported technologies and capital to address innovation needs. All of which, on balance, makes an MIT more likely to occur.

An aging work force and rising dependence on that segment (i.e., those who continue working) to fund the social safety nets can also contribute to economic stagnation and, eventually, a MIT. These factors are not yet in play in Poland, where the working age population share exceeded 60 percent throughout the examined period (peaking in 2008-2009 and declining slightly thereafter). The labor participation rate also demonstrated an inverse trend - reaching 57 percent in 1999, retreating in 2007 to 53 percent, and then recovering to 56.3 percent in 2016 (Trading Economics, 2017) Poland's dependency rate (i.e., persons aged 16 or less and over 65 as a percentage of the total population) is 43.8 percent. This is less than that of Germany (51.62 percent), the Czech Republic (49.52 percent) and Hungary (47.91 percent), suggesting a relatively higher percentage of labor is of working age, which would impose a relatively low strain on the government budget (IndexMundi, 2016).

This favorable situation may worsen in the future. The Polish government recently reduced the retirement age to below 65 , which places the retirement age below those in most EU countries. To date, however, the limited data available do not indicate that Poland's demographics now threaten its economic growth.

The structure and composition of exports are also a primary engine of sustainable economic growth. Countries seeking to develop their economies from stage III often switch away from exports that are labor intensive or rely on FDI and technology imports towards domestic innovation to produce capital and technology intensive products. During the years 2000 through 2016, Polish exports grew threefold, and also changed by sector. However, those changes do not clearly support Poland's progression from stage III to stage IV.

More specifically, in 2004 machinery and equipment accounted for the highest share of Polish exports (21.9 percent), followed by metals and semifinished metal products (12.57 percent), minerals (5.73 percent), plastics and rubber products (5.14 percent), chemicals (5.06 percent), textiles (4.9 percent), food and tobacco products (3.73 percent), and wood and paper products (3.21 percent) (Statistics Poland, 2017). Twelve years later, in 2016, the percentage of total exports was: machinery including computers, (13.1 percent of total exports), vehicles (12.2 percent), electrical machinery and equipment (11.5 percent), furniture (6 percent), plastics (4.7 percent), articles of iron or steel (3 percent), mineral fuels including oil (2.6 percent) and meat (2.2 percent) (Workman, 2017).

These highly aggregated export categories make it difficult to draw firm conclusions about the extent of value-added resting on Poland's skilled labor or technology in those exports. Nevertheless, several structural changes in Polish export composition bear mention. Computers and vehicles, which were absent in 2004, had become among the largest categories of Poland's exports in 2016. But this shift can be explained by reasons other than a higher Polish export innovation content. In fact, because EU 
firms often use less expensive Polish labor to produce vehicles and other machinery in Poland, this shift in export composition may reflect the use of innovation developed and controlled by entities outside Poland.

This does not suggest that no Polish exports have become more advanced and include a higher domestic value added. For example, in 2016 metals and semi-finished metal products, minerals, and textiles (all of which are typically low value-added exports) dropped from Poland's largest ten export categories, and were replaced by higher export shares of equipment and machinery. The latter tend to have higher domestic value added. That said, Polish exports continue to lean heavily on foreign capital and technology and the use of relatively inexpensive domestic Polish labor and the observed export shift from textiles, minerals, and food products to more technology-based exports therefore does not necessarily protect Poland from the MIT. Unfortunately, short of measuring locally value added from structural statistics, which is beyond the scope of this paper, data do not permit us to disaggregate value added created by Polish labor, which would enhance our ability to evaluate the structural changes in Poland's exports.

Another way to assess foreign versus domestic innovation in exports is through the World Bank Enterprise Survey Study, which measures reliance by domestic firms on foreign technology (World Bank 2020). According to that Survey, in 2019 approximately 12 percent of Poland's firms relied on foreign technology (as compared to 7 percent in 2006), which - by way of comparison - is two times higher than the reliance of firms in Brazil. High reliance on foreign technology, however, does not alone signal an MIT threat, but should be considered with other indicators, including the type and sector where foreign technology is employed and its impact on domestic innovation.

Further insight into Poland's progress on domestic innovation and production of complex goods is provided by the data from The World Bank (2016) on country specific product mix and export specialization. These data further confirm the key role of machinery in Poland's exports; specifically, transportation equipment, led by automobiles, assembled in Poland with foreign capital and technology. Two other top Polish export concentration groups - food and agricultural products - suggest that Poland has not yet achieved the economic complexity and export diversification commonly identified as facilitating stage IV sustainable growth.

Indeed, Poland's economic complexity score (based on the scoring methodology of Hausmann and Hidalgo (2009), which extends traditional inputs such as labor, capital, land and technology by adding infrastructure, laws, institutions, collective knowledge and other non-tangible inputs) has not materially advanced.While, the Hidalgo index ignores the country of incorporated value added, nevertheless, Poland's Economic Complexity Index (ECI) ranking has remained roughly stable over the last decade, changing for from 23rd in 2000 to $22 \mathrm{nd}$ in 2016 (ECI 2018).

The literature examining Poland's FDI structure provides meaningful, but limited, data on the extent of modernization and reliance on domestic versus foreign innovation in Polish production (Woo, J. \& Heo, U. 2009). A comparison of changes in the accumulated stock of FDI in Poland in the 2005 to 2015 reveals an increase from 24 to 40 percent in the total share of FDI in Poland's GDP (Ancyparowicz, 2009). During much of this period manufacturing, transportation equipment, and food processing received the most foreign capital. In 2015, however, services registered the largest share in FDI primarily through financial intermediaries (19 percent) and commerce (16 percent). Like changes to Poland's export structure, changes to (and increased reliance on) FDI composition suggests that the Polish economy has not yet reached stage IV of economic development, because it still depends on foreign capital for technology and relies on low labor costs to attract manufacturing opportunities.

It is worth noting here that the profitability of FDI in Poland has been one of the highest within OECD countries, reaching almost 10 percent in 2015. In the same year, Poland's rate of return on its outward FDI was 3.2 percent (OECD, 2017b). However, profits earned by foreign owned companies operating in Poland were included in Polish GDP, even though, on average, more than 40 percent of those profits were repatriated to the "home countries" of Polish firms 
and expended outside Poland. (Narodowy Bank Polski 2015). These high rates of profits and their high share of repatriation signal forgone opportunities for Poland, representing foreign money that was not reinvested to support the domestic economy or domestic innovation.

\section{Policy Considerations}

The core question that our MIT analysis addresses is whether those elements of Poland's economy that have powered that country's rapid development and growth over the last twenty years will also propel it into a modern stage IV economy. The data and reasoning presented in this paper suggests that Poland - currently at stage III of its economic development - is currently positioned between two potential outcomes; that is, gradual stagnation or continued growth.

On the growth side, several factors we have examined evidence that several systemic threats often associated with an MIT are absent. The most noteworthy of those factors is productivity growth. Measuring productivity growth on a macroeconomic scale, while problematic, often provides useful insights. We rely here on total factor productivity and GDP growth per hour, which do not reveal signs of a slowdown. Another - education - exhibits a rapid increase in the share of Poles that have earned tertiary degrees. This is decidedly pro-growth. As is Poland's demographics (in terms of dependency ratios and aging), which both generally support the transformative growth that economy's need to avoid an MIT.

Other observed factors are more consistent with stagnation, suggesting that Poland should consider whether certain proactive steps are warranted to increase its future economic growth prospects. For example, Poland's success since joining the EU has been meaningfully aided by the high and rising share of public investment financed by that organization through infrastructure funds. To facilitate a continued flow of investment, which remains a key element of future economic growth, Poland must eventually address the frequent levelled (and arguably justified) criticism from Brussels about its inability to adequately absorb those funds (Kersan et al., 2017). Among the steps that have been suggested to increase absorption are modifying relevant institutional and regulatory frameworks, simplifying public procurement rules, eliminating the requirement of ministerial-level approvals of all documented requirements, limiting recourse by unsuccessful bidders to the courts concerning for low value (i.e., under 100,000 Euros) projects, and simplifying the claims process regarding EU refunds to successful bidders after a project is completed.

The share of private investment in Poland also needs to be increased. Doing so may entail a more businessfriendly regulatory framework, streamlined business registration procedures, and carefully monitoring the impact of the recent reforms to the insolvency law. Restrictive labor laws and irregular work relationships should also be targeted, as they have the tendency to discourage small and medium-size business investment and growth, undermine labor productivity, and can be obstacles to firms seeking to hire new workers (OECD, 2016).

Another factor that, over time, will likely increase the threat of an MIT is the lowering of Poland's retirement age to 60 for women and 65 for men, which is a roll back from the age 67 year retirement age for men and women approved by the prior government in 2012 . While the impact of this policy change cannot yet be assessed statistically, one almost certain consequence will be to negatively impact Poland's future dependency ratios and, potentially, growth, by increasing the number of retired persons who are otherwise able to actively participate in the labor force. Most Polish retirees rely exclusively on the state for their pensions.

A third area of general concern is Poland's persistent (and current) low R\&D spending, which suggests a lack of government support. This situation distinguishes Poland from other stage III countries that rely on government-funded R\&D as a critical support for innovation (e.g., the U.S., Japan, South Korea, and Taiwan), particularly in products for which high risks and costs are required to produce disruptive technological advances.

And, while Poland's changing foreign trade structure does indicates a shift away from manufacturing low value-added exports and towards more advanced products, both Polish exports and FDI still rest on relatively lower labor costs to produce goods based on imported technologies. This reliance is signaled, in part, by a lack of improvement in Poland's economic complexity over that last decade, as the country continues to rely heavily on FDI for modern capital and technology. One pos- 
sible option to increase FDI's in domestic growth could be to change the regulations guiding repatriations. While this often discourages FDI, the negative impact of such regulation might be somewhat mitigated by the continued high profitability of FDI in Poland.

\section{Conclusions}

Whether the MIT exists and what systemic factors contribute and characterize it are the subject of debate in the literature. Plainly, though, the economies of middle-income countries whose growth is too tied to high value-added imports (including technology and FDI), and exports that embed foreign technology and/ or capital, are not well-diversified. Inevitably, a lack of diversity impacts long-term growth sustainability. We have examined a number of factors in this paper that are typically present in an economy approaching a point of economic "switch," using a case study of Poland. Our examination has yielded mixed results.

Factors that may mitigate the MIT threat to Poland include rising TFP and high educational attainments. At the same time, a number of potentially problematic areas are clearly present. These problematic areas include Poland's declining competitiveness ranking, a slow-down in investment (which is dominated by public/EU funds primarily expended on infrastructure and not on innovation), the weak absorption of skilled labor and consequent brain drain, relatively low R\&D spending, the limited number of patents and research and innovation at the local level, and heavy reliance of foreign capital and technology in the content of exports as well as in FDI. These factors collectively suggest that Poland has not shifted its growth towards domestic technologies and innovation, which characterizes stage IV economies. If left unaddressed, such factors may (alone and in combination) hinder Poland's future development and economic growth.

\section{References}

Ancyparowicz, G. (2009). Wplyw bezpośrednich inwestycji zagranicznych na wzrost polskiej gospodarki $w$ okresie poakcesyjnym [The impact of direct foreign investments on the growth of the Polish economy in the post-accession period]. Statistics Poland, Financial Statistics Department. stat.gov.pl/cps/rde/xbcr/gus/pgw_ wplyw_bezp_inwest_zagr_na_wzrost_pol_gosp. pdf
Baumol, W. (1967). Macroeconomics of unbalanced growth: The anatomy of urban crisis. The American Economic Review 57(3), 415-426.

Eichengreen, B. (2011). Escaping the middle-income trap. Proceedings - Economic Policy Symposium Jackson Hole, 409-19. Federal Reserve Bank of Kansas City. https://citeseerx.ist.psu.edu/view$\mathrm{doc} /$ download?doi=10.1.1.639.7830\&rep=rep1\& type $=$ pdf

European Commission. (2020). European Innovation Scoreboard 2020. https://ec.europa.eu/commission/presscorner/detail/en/qanda_20_1150

Eurostat (2019). Hourly labour costs. https://ec.europa. eu/eurostat/statistics-explained/index.php/Hourly_labour_costs

Felipe, J. (1999). Total factor productivity growth in East Asia: A critical survey. Journal of Development Studies, 35(4), 1-41. https://doi. org/10.1080/00220389908422579

Gill, I., \& Kharas, H. (2007). An East Asian renaissance: Ideas for economic growth. World Bank.

Griffith, B. (2011). Middle-income trap. In R. Nallari, S. Yusuf, R. Bhattacharya (Eds.), Frontiers in Development Policy: A Primer on Emerging Issues (pp. 39-43). World Bank.

Hayat, A. (2018). FDI and economic growth: the role of natural resources? Journal of Economic Studies, 45 (2), 283-295. https://doi.org/10.1108/JES05-2015-0082

Hidalgo, C. A., \& Hausmann, R. (2009). The building blocks of economic complexity. Proceedings of the National Academy of Sciences, 106(26), 1057010575.

IMD World Competitiveness Center. (2018). World Competitiveness Center rankings. https://www. imd.org/wcc/world-competitiveness-center-rankings/world-competitiveness-ranking-2018/

IMD World Competitiveness Center. (2019). IMD World Competitiveness ranking 2019:

One year change. https://www.imd.org/contentassets /6b85960f0d1b42a0a07ba59c49e828fb/one-yearchange-vertical.pdf

IndexMundi. (2016). Age dependency ratio. www.indexmundi.com/facts/indicators/SP.POP.DPND/ compare? country=de\# country $=c z$ :de:hu:pl

IndexMundi. (2017). Poland dependency ratios. www. indexmundi.com/poland/dependency_ratios. html

Jankowska, A., Nagengast, A., \& Perea, J. (2012). The product space and the middle-income trap: comparing Asian and Latin American experiences (OECD Development Centre Working 
Paper No. 311). OECD Publishing. https://doi. org/10.1787/18151949

Jimenez, E. (2012). Stuck in the Middle? Human Capital Development and Economic Growth in Malaysia and Thailand (Policy Research Working Paper No. WPS 6283). World Bank. https://ssrn.com/ abstract $=2183584$

Kersan-Škabić, I., \& Tijanić L. (2017). Regional absorption capacity of EU funds. Economic Research-Ekonomska Istraživanja, 30(1), 1191-1208. Taylor \& Francis Online. https://doi.org/10.1080/ 1331677X.2017.1340174

Khan, M., (2016). World intellectual property indicators 2016: Economics \& Statistics Series. The Journal of World Intellectual Property, 19.5-6 Web. https://www.wipo.int/edocs/pubdocs/en/wipo_ pub_941_2016.pdf

Leibfritz, W. \& Roeger, W. (2008). The effects of aging on labor markets and economic growth. In I. Hamm, H. Seitz, M. Werding (Eds.), Demographic Change in Germany (pp. 35-63). Springer.

Martin, F. (2017, February 9). Why Does Economic Growth Keep Slowing Down? St. Louis Fed On the Economy Blog. https://www.stlouisfed.org/on-theeconomy/2017/february/why-economic-growthslowing-down

Mishal, Z., \& Abulaila, Z. (2007). The impact of foreign direct investment and imports on economic growth: The case of Jordan. Journal of Economic and Administrative Sciences, 23, 1-31. https://doi. org/10.1108/10264116200700001

North, D. (1989). Institutions and economic growth: An historical introduction. World Development, 17(9), 1319-1332. https://doi.org/10.1016/0305750X(89)90075-2

Narodowy Bank Polski. (2015). Foreign direct investment in Poland and Polish direct investment abroad in 2015. https://www.nbp.pl/publikacje/pib/FDI_ report_2015_en.pdf

Organisation for Economic Co-operation and Development. (2016). OECD economic surveys: Poland. https://www.oecd-ilibrary.org/economics/oecdeconomic-surveys-poland-2016_eco_surveyspol-2016-en 